fatty acid (Barrett et al., 1968), and, unlike propranolol, practolol was also found to have some intrinsic sympathomimetic action (Sowton et al., 1968) and no local anaesthetic (quinidine-like) action (Dunlop and Shanks, 1968). In view of these considerations practolol might be expected to exert a less adverse effect on myocardial function than propranolol. A negative inotropic effect, however, has been found by Gibson and Sowton (1968) and Sowton et al. (1968) when using a large intravenous dose of $25 \mathrm{mg}$., though it was not evident with a 5-mg. dose of practolol. Possibly the significant fall in systolic pressure (lying and standing) produced by practolol in the present study may represent a negative inotropic effect, though the accompanying fall in heart rate induced by practolol may also be an important factor in this respect. There is as yet no convincing evidence that practolol can be given with impunity to patients with cardiac failure, and it would be advisable to continue to administer the drug cautiously when myocardial dysfunction is present.

The bronchospastic effect of propranolol has been confirmed in the present study, while practolol was found to exert no significant effect on small airway resistance in our 15 patients. This confirms other studies showing that doses of practolol which were capable of blocking cardiac betareceptors had no significant effects on the beta-receptors of vascular and bronchial smooth muscle (Barrett et al., 1968; Dunlop and Shanks, 1968; McDonald and McNeill, 1968). This represents an important advantage of practolol over propranolol, since it means that practolol can be used freely in a large section of the population with combined angina and asthmatic bronchitis, where propranolol may adversely affect the respiratory function.

The blood pressure response to practolol in the present study is worthy of comment. It has been claimed that practolol has no significant effect on vascular smooth muscle, but there was a significant fall in the standing diastolic pressure following treatment with the drug. This suggests that practolol in the dose range used in the present study does in fact have some effect on the peripheral arterioles, and this may well have been an important factor in the patient who developed severe hypotension while having practolol and had to be withdrawn from the trial. Hence a close watch should be kept on the blood pressure whenever an anginal patient is treated with practolol, just as similar close observation is required with propranolol treatment.

We are grateful to Mr. B. Bamford and Miss V. Clarke for technical assistance with the electrocardiography. We should also like to thank Dr. W. H. M. Jewell, of I.C.I. Ltd., for supplies of drugs used in the trial; and Mr. A. M. Tucker for help with the statistical analysis.

\section{REFERENCES}

Areskog, N. H., and Adolfsson, L. (1969). British Medical fournal, 2, 601.

Barrett, A. M., Crowther, A. F., Dunlop, D., Shanks, R. G.; and Smith, L. H. (1968). Naunyn-Schmiedeberg's Archiv für Pharmakologie und experimentelle Pathologie, 259, 152.

Bellet, S., Eliakim, M., Deliyiannis, S., and La Van, D. (1962). Circu-

Birkett, D. A., and Chamberlain, D. A. (1966). British Medical fournal, 2, 500

Black. J. W., Crowther, A. F., Shanks, R. G., Smith, L. H., and Dornhorst, A. C. (1964). Lancet, 1, 1080

Chamberlain, D. A. (1966). Cardiologia, 49, Suppl. No. 2, p. 27.

Dornhorst, A. C., and Robinson, B. F. (1962). Lancet, 2, 314.

Dunlop, D., and Shanks, R. G. (1968). British Fournal of Pharmacology and Chemotherapy, 32, 201.

Fitzgerald, J. D., and Scales, B. (1968). Internationale Zeitschrift für Klinische Pharmakologie, Therapie und Toxikologie, 1, 467.

Gibson, D., and Sowton, E. (1968). British Medical fournal, 1, 213.

2, 337 Grant, R. H. E., et al. (1966). American fournal of Cardiology, 18,

Greiner, T., et al. (1950). American fournal of Medicine, 9, 143.

Hamer, J., Grandjean, T. Melendez, L., and Sowton, G. E. (1964). British Medical fournal, 2, 720.

Hamer, J., and Sowton, E. (1966). American fournal of Cardiology, 18, 354.

Keelan, P. (1965). British Medical fournal, 1, 897.

Leuallen, E. C., and Fowler, W. S. (1955). American Review of Tuberculosis and Pulmonary Diseases, $72,783$.

Lloyd-Thomas, H. G. (1961). British Heart fournal, 23, 561.

Macdonald. A. G., and McNeill, R. S. (1968). British fournal of Anaesthesia, 40, 508.

McNeill, R. S. (1964). Lancet, 2, 1101.

Master, A. M., and Rosenfeld, I. (1961). Fournal of the American Medical Association, 178, 283.

Sandler, G. (1961). British Medical fournal, 1, 792.

Sandler, G. (1967). British Heart fournal, 29, 719.

Sandler, G., Clayton, G. A., and Thornicroft, S. G. (1968). British Medical fournal, 3, 224 .

Shanks, R. G. (1966). American fournal of Cardiology, 18, 308.

Sowton, E.. Balcon, R., Cross, D., and Frick, H. (1968). British Medical Fournal, 1, 215.

Stephen, S. A. (1966). American fournal of Cardiology, 18, 463.

Wilcoxon, F. (1945). Biometrics, 1, 80.
Wolfson, S., et al. (1966). American fournal of Cardiology, 18, 345.

\title{
Practolol in Treatment of Angina Pectoris. A Double-blind Trial
}

\author{
C. F. GEORGE, ${ }^{*}$ M.B., M.R.C.P. ; R. E. NAGLE, $†$ M.B., M.R.C.P. ; B. L. PENTECOST, $†$ M.D., M.R.C.P.
}

British Medical fournal, 1970, 2, 402-404

\begin{abstract}
Cummary: Twenty-four patients with angina pectoris $\checkmark$ entered a double-blind trial of the cardioselective beta-adrenergic blocking agent practolol. Seventeen experienced less angina and consumed fewer glyceryl trinitrate tablets when on the active preparation. There was also a decrease in the mean number of attacks suffered by patients while on practolol and a reduction in the number of glyceryl trinitrate tablets taken. These results are of statistical significance at, at least, the $5 \%$ level.
\end{abstract}

\section{Introduction}

Pharmacological blockade of the sympathetic nervous impulses to the heart is now an accepted method of treatment for angina (British Medical fournal, 1969). In a number of clinical trials propranolol has been shown to reduce the fre-

* Medical Registrar, the General Hospital, Birmingham 4.

t Consultant Physician, the United Birmingham Hospitals. quency of angina attacks and the consumption of glyceryl trinitrate (Gillam and Prichard, 1965; Keelan, 1965; Grant et al., 1966; Gianelly et al., 1967). All beta-adrenergic agents, however, may increase airways resistance, especially when there is a tendency to asthma (MacDonald et al., 1967). As angina and obstructive airways diseases. not uncommonly exist in the same patient, the respiratory problems may be aggravated and prevent the administration of the optimum dose of beta-blocking drug. Practolol is cardioselective and causes less increase in airways resistance than propranolol (MacDonald and McNeill, 1968). A preparation of this kind could offer certain practical advantages over propranolol. Therefore a controlled trial was conducted in order to assess the efficacy of practolol in angina pectoris.

\section{Patients and Methods}

The first aim was to establish the dose of practolol at which symptomatic relief was obtained, but an arbitrary upper limit 
of 1,200 mg. daily was set. The half-life of practolol is 10 hours as compared with two hours of propranolol (FitzGerald and Scales, 1968); less frequent administration of the drug is therefore possible. The initial dose of practolol was $200 \mathrm{mg}$. twice daily, and increments of $200 \mathrm{mg}$. daily were made at fortnightly intervals until the patient claimed considerable improvement or until the maximum dose had been reached. The "run-in" period, which varied from 6 to 17 weeks, was designed to reduce the placebo effect of frequent attendances as an outpatient. On each occasion the sitting pulse and blood pressure were recorded and blood was taken for estimation of haemoglobin, total and differential white cell counts, platelet count, urea, liver function test, and serum practolol levels. The urine was tested for protein and sugar and the deposit examined microscopically. Chest radiographs were taken on all patients before starting treatment and again when stabilized on practolol.

Twenty-seven patients with typical angina pectoris entered the "run-in" period. Two were unable to tolerate the drugone complained of abdominal distension and dyspnoea and the other of tiredness and dizziness which was not associated with hypertension. A third was not considered reliable enough to take part in the formal trial. One patient involved in the trial could tolerate only $200 \mathrm{mg}$. daily, larger doses causing a sensation of weakness and fatigue. Twenty-four patients (19 men and 5 women) entered the double-blind trial. Their ages ranged from 46 to 70 years. In four there was unequivocal evidence of a previous myocardial infarction which had occurred at a minimum of six months before the start of the study period. Two patients were diabetic, neither of them requiring insulin. Only one patient was receiving drug therapy for cardiac failure.

Patients were given cards on which to record the daily number of attacks of angina experienced and the number of glyceryl trinitrate tablets taken. No instructions were given against the taking of prophylactic glyceryl trinitrate as several of the patients had been accustomed to taking the drug in this manner for a number of years. It was explained that the treatment would be varied during the period of study in order to assess the true value of the drug therapy; all the patients consented to take part in the trial.

The trial was double-blind and lasted 12 weeks. Each patient received practolol for two periods of three weeks and placebo preparation for two similar periods. The order in which the drug and identical placebo were given was randomized. Patients were seen at intervals of three weeks by the same physician. Neither the interviewing physician nor the patient was aware whether practolol or placebo was being taken.

\section{Results}

The mean heart rate of the group was significantly $(\mathrm{P}<0.005)$ reduced when on the active preparation, averaging 69 beats/minute (range 58-92) compared with 79 beats/minute (range 58-108) on placebo. The mean systolic and diastolic blood pressure was 138/85 while on practolol and 145/90 while on placebo this is statistically significant. Only five diastolic recordings in excess of $100 \mathrm{~mm} . \mathrm{Hg}$. were ebtained in patients on practolol compared with nine during periods on placebo.

The frequency of angina pectoris and the consumption of glyceryl trinitrate during the trial are shown in the Table. Of the 24 patients, 21 completed the trial and 14 of these showed a reduction in the incidence of anginal pain and used less glyceryl trinitrate. While on the placebo the three others experienced frequent or continuous severe pain, which was unrelieved by glyceryl trinitrate. All three had previously improved while on the active tablets. They were withdrawn from the trial, and reintroduction of practolol resulted in relief of the angina.

Cases 4 and 13 had been on substantial doses of propranolol
Episodes of Angina and Consumption of Glyceryl Trinitrate

\begin{tabular}{|c|c|c|c|c|c|c|c|}
\hline \multirow[t]{2}{*}{$\begin{array}{l}\text { Case } \\
\text { No. }\end{array}$} & \multirow[t]{2}{*}{ Sex } & \multirow[t]{2}{*}{ Age } & \multirow[t]{2}{*}{$\begin{array}{c}\text { Daily } \\
\text { Dose in } \mathrm{mg} \text {. }\end{array}$} & \multicolumn{2}{|c|}{$\begin{array}{l}\text { Episodes of } \\
\text { Angina }\end{array}$} & \multicolumn{2}{|c|}{$\begin{array}{c}\text { Tablets of } \\
\text { Glyceryl Trinitrate }\end{array}$} \\
\hline & & & & Practolol & Placebo & Practolol & Placebo \\
\hline $\begin{array}{r}1 \\
2 \\
3 \\
4 \\
5 \\
6 \\
7 \\
8 \\
9 \\
10 \\
11 \\
12 \\
13 \\
14 \\
15 \\
16 \\
17 \\
18 \\
19 \\
20 \\
21 \\
22 \\
23 \\
24\end{array}$ & $\begin{array}{l}M \\
M \\
M \\
M \\
M \\
F \\
M \\
M \\
M \\
F \\
M \\
M \\
M \\
M \\
F \\
M \\
M \\
M \\
F \\
M \\
M \\
M \\
F \\
M\end{array}$ & $\begin{array}{l}47 \\
54 \\
61 \\
64 \\
51 \\
61 \\
55 \\
53 \\
66 \\
60 \\
70 \\
63 \\
51 \\
55 \\
61 \\
54 \\
54 \\
46 \\
48 \\
47 \\
60 \\
51 \\
62 \\
62\end{array}$ & $\begin{array}{r}600 \\
400 \\
600 \\
700 \\
700 \\
800 \\
600 \\
800 \\
1,000 \\
600 \\
900 \\
900 \\
400 \\
800 \\
800 \\
1,200 \\
1,200 \\
1,200 \\
1,000 \\
1,200 \\
400 \\
600 \\
600 \\
200\end{array}$ & $\begin{array}{r}38 \\
0 \\
16 \\
3 \\
25 \\
20 \\
23 \\
69 \\
163 \\
19 \\
33 \\
79 \\
2 \\
56 \\
16 \\
80 \\
86 \\
81 \\
79 \\
31 \\
18 \\
52 \\
54 \\
167\end{array}$ & $\begin{array}{c}94 \\
5 \\
46 \\
6 \\
37 \\
27 \\
13 \\
54 \\
195 \\
31 \\
21 \\
100 \\
26^{*} \\
130^{*} \\
{ }^{\dagger} \\
167^{*} \\
65 \\
84 \\
49 \\
29 \\
17 \\
73 \\
82 \\
172\end{array}$ & $\begin{array}{r}22 \\
0 \\
3 \\
0 \\
11 \\
20 \\
23 \\
3 \\
750 \\
30 \\
217 \\
77 \\
21 \\
84 \\
52 \\
80 \\
128 \\
95 \\
52 \\
31 \\
18 \\
52 \\
54 \\
167\end{array}$ & $\begin{array}{r}63 \\
7 \\
6 \\
3 \\
18 \\
27 \\
13 \\
0 \\
783 \\
55 \\
207 \\
80 \\
37^{*} \\
161 \\
165^{*} \\
101 \\
99 \\
33 \\
24 \\
17 \\
73 \\
82 \\
172\end{array}$ \\
\hline
\end{tabular}

*Withdrawn from trial during the first placebo period after three weeks' active treatment because of severe and frequent angina.

This patient experienced 16 episodes of angina in six weeks on practolol. In the third period of the trial (first placebo period) he had 14 episodes of pain in eight days followed by almost continuous pain for the next six days. He was withdrawn from the trial.

before changing to practolol. They are of particular interest since they illustrate certain therapeutic differences between the two drugs.

Case 4.-A 64-year-old man had experienced severe angina pectoris for several months when treatment was started with propranolol 40 mg. q.d.s. in December 1967. In February 1968 his angina increased in severity and the dose of propranolol was doubled, with considerable relief of angina but at the expense of severe bronchospasm and pronounced bradycardia, 40-42 per minute. Reduction in the dose of propranolol failed to relieve the bronchospasm though his pulse rate increased to 62. Practolol $200 \mathrm{mg}$. b.d. was substituted for propranolol in August 1968; the bronchospasm ceased, and the frequency and severity of angina once again diminished.

Another patient with chronic bronchitis (Case 21) was able to tolerate practolol without increase in dyspnoea though he failed to show improvement of angina during the trial.

Case 13.-A 51-year-old man with diabetes mellitus had suffered from angina pectoris since 1961. His angina worsened in 1967 and propranolol was given in January 1968. There was, however, no symptomatic relief on a daily dose of $400 \mathrm{mg}$., which produced a resting pulse rate of 64. In January 1969 practolol was substituted and he experienced no attacks of angina during the first two months of the "run-in" period. At this stage he entered the double-blind trial and in the first three weeks on practolol experienced two attacks of angina. While taking the placebo he had 26 attacks of angina in 13 days and the pain was not relieved by glyceryl trinitrate. He was withdrawn from the trial at this stage, and two days later, after restarting practolol, became free of pain and has remained so up to the time of writing

The existence of well-controlled cardiac failure is not necessarily a contraindication to practolol. A 51-year-old man (Case 22) who had frequent angina following myocardial infarction was receiving digitalis and diuretic therapy for left ventricular failure. Practolol $600 \mathrm{mg}$. daily brought a reduction in frequency of the attacks of angina without producing deterioration in the degree of failure.

No evidence of bone marrow depression, nephrotoxicity, or liver dysfunction was encountered in patients taking practolol. Eleven have now taken the preparation for periods in excess of six months. There has been no clinical evidence of any adverse effect on their health. Occasionally they complained of a vague sense of fatigue, but this appeared to be less than with propranolol. In two patients an increase in heart size was shown on posteroanterior standard radiographs when taking 
practolol but there was no evidence of cardiac failure. Blood levels of the drug were variable, but showed a tendency to rise with increasing dosage (see Chart). The estimations are of some value in providing evidence that the patients were in fact taking the drug. One patient (Case 17) who experienced more angina during active therapy than during placebo had no detectable blood levels of practolol at any time. He claimed to be taking his medication, and for this reason has not been eliminated from the trial.

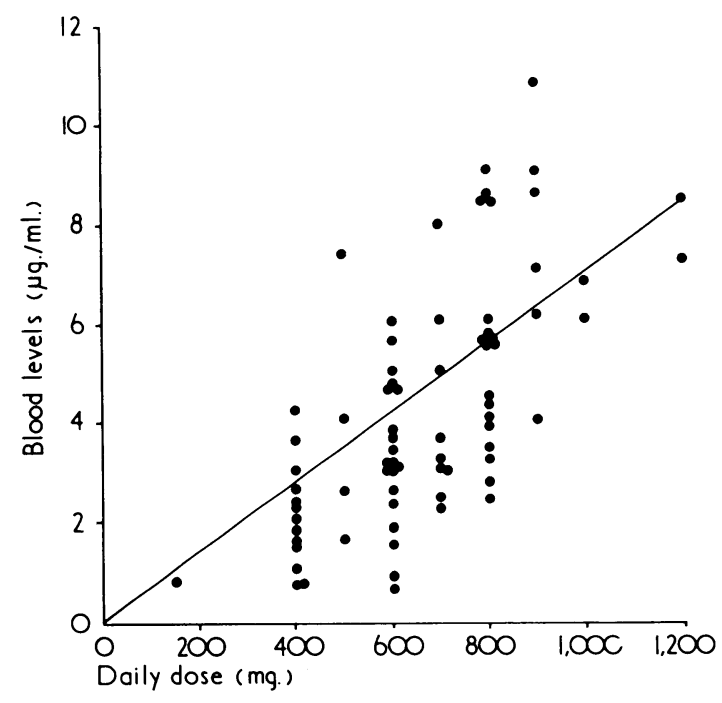

Correlation between blood levels and daily dose of practolol.

\section{Discussion}

In this trial only the most elementary clinical haemodynamic observations have been made, and it cannot be claimed that such a study will help our understanding of the way in which beta-adrenergic blockade produces relief from symptoms in angina pectoris. This matter has been the subject of several recent reviews and is not debated further here. It is sufficient to note that the resting heart rate and blood pressure before treatment did not serve as a guide to which patients would benefit from therapy. This experience is similar to that of other workers (Gianelly et al., 1967).

Of 24 patients with angina pectoris, 17 showed reduction of the frequency of angina attacks when taking practolol. In only eight patients was the frequency reduced by $50 \%$ or more when compared with that observed in the placebo period. In a further five the frequency was reduced between 25 and $50 \%$, and in the remaining four by less than $25 \%$. This compares unfavourably with some studies using propranolol. Gillam and Prichard (1965) showed a reduction of $50 \%$ or more in the frequency of angina in 10 out of 14 patients, and Gianelly et al. (1967) observed a similar improvement in 8 out of 19 patients. The overall improvement rate too is less than that noticed by these workers and by Grant et al. (1966). This apparent superiority of propranolol may be explained by the fact that we prescribed insufficient practolol to achieve its maximum therapeutic effect. This was a common problem in the early trials of propranolol. Nevertheless, clearly some of the failure of practolol therapy occurred among patients receiving the maximum dosage of 1 to $1.2 \mathrm{~g}$. daily. An alternative explanation is that practolol, unlike propranolol, has some inherent sympathomimetic activity (Dunlop and Shanks, 1968), but, nevertheless, Areskog and Adolfsson (1969) found an improvement in exercise tolerance among patients with angina pectoris following intravenous injection of the preparation. In a similar acute study on a treadmill we found an improvement in three out of six patients (Nagle and Pentecost, 1969).

Practolol seems to offer a useful alternative to propranolol in patients with coexistent angina and obstructive airways disease, as in two patients in the present study. This point is further illustrated by another patient under our care with hypertrophic obstructive cardiomyopathy and chronic bronchitis with severe bronchospasm. This patient's presenting symptoms were angina and dyspnoea. There has been considerable symptomatic improvement on practolol $400 \mathrm{mg}$. daily. Objectively the murmur of left ventricular outflow tract obstruction is less evident than before and bronchospasm has become less pronounced. During this period serial estimations of peak respiratory flow have improved. The report on Case 13 suggests that practolol may produce improvement when quite high doses of propranolol have failed to do so, even in the absence of respiratory disease. There is, unfortunately, still no simple guide regarding which patients will respond to betaadrenergic therapy and there is no alternative to a trial of therapy in any patient with frequent troublesome angina pectoris; nor does it appear certain that failure to respond to one beta-blocking agent means that another will not produce a beneficial effect.

We gratefully acknowledge the help of Dr. R. A Wiseman, Dr. M. Jewell, and Dr. J. D. FitzGerald, of I.C.I., who supplied the practolol and placebo tablets and arranged for statistical analysis. Dr. B. Scales, of I.C.I., performed the serum estimation of practolol.

REFERENCES

Areskog, N.-H., and Adolfsson, L. (1969). British Medical fournal, 2 , 601

British Medical fournal, 1969, 2, 134.

Dunlop, D., and Shanks, R. G. (1968). British fournal of Pharmacology and Chemotherapy, 32, 201.

FitzGerald, J. D., and Scales, B. (1968). Internationale Zeitschrift für klinische Pharmacologie, Therapie und Toxikologie, 1, 467.

Gianelly, R. E., Goldman, R. H., Treister, B., and Harrison, D. C. (1967). Annals of Internal Medicine, 67, 1216.

Gillam, P. M. S., and Prichard, B. N. C. (1965). British Medical fournal, 2, 337. S., and Prichard, B. N. C. (1965). British Medical fournal,
Grant, R. H. E., et al. (1966). American fournal of Cardiology, 18,

361. Keelan, P. (1965). British Medical fournal, 1, 897.

Macdonald, A. G., Ingram, C. G., and McNeill R. S. (1967). British 7ournal of Anaesthesia, 39, 919.

Macdonald, A. G., and McNeill, R. S. (1968). British fournal of Anaesthesia, 40, 508.

Nagle, R. E., and Pentecost, B. L. (1969). Unpublished data. 